\title{
Faktor Yang Berhubungan Dengan Pemanfaatan Puskesmas Oleh Masyarakat Di Wilayah Kerja Puskesmas Pasar Terusan
}

\author{
Titik Sandora*1, Entianopa $^{1}$, Renny Listiawaty ${ }^{1}$ \\ 1.Program Studi Kesehatan Masyarakat, Sekolah Tinggi Ilmu Kesehatan Harapan Ibu \\ Jambi, Indonesia
}

Author's Email Correspondence (*): entianopa23@gmail.com

Phone : +6285266374038

\begin{abstract}
ABSTRAK
Pemanfaatan pelayanan kesehatan menjadi suatu permintaan bagi konsumen berdasarkan kebutuhan dari rasa sakit, ketidaknyamanan maupun keinginan untuk pencegahan akan suatu penyakit. Data Dinas Kesehatan Kabupaten Batanghari tahun 2019 diketahui bahwa Puskesmas Pasar Terusan memiliki persentase kunjungan pasien baru paling rendah yaitu sebesar 19,2\%. Desain penelitian adalah cross sectional. Penelitian dilakukan di wilayah kerja Puskesmas Pasar Terusan pada bulan Juli 2020. Sampel penelitian adalah masyarakat yang ada di wilayah kerja Puskesmas Pasar Terusan sebanyak 95 orang. Teknik pengambilan sampel menggunakan teknik purposive sampling. Instrumen yang digunakan adalah kuesioner. Data dianalsis menggunakan uji chi-square. Hasil penelitian diketahui 41,1\% responden tidak memanfaatkan pelayanan puskesmas, 32,6\% memiliki pengetahuan kurang baik, 34,7\% mendapatkan informasi kurang lengkap, 34,7\% memiliki keterjangkauan sulit dan 35,8\% menyatakan sikap petugas kurang baik. hasil bivariat menunjukkan bahwa ada hubungan antara pengetahuan $(\mathrm{p}=0,000)$, keterjangkauan $(\mathrm{p}=0,030)$ dan sikap petugas $(\mathrm{p}=0,000)$ dengan pemanfaatan pelayanan puskesmas di wilayah kerja Puskesmas Pasar Terusan Tahun 2020. Tidak ada hubungan antara informasi dengan pemanfaatan pelayanan puskesmas di wilayah kerja Puskesmas Pasar Terusan Tahun 2020 $(\mathrm{p}=0,646)$. Puskesmas perlu memperluas jaringannya untuk menjangkau masyarakat yang memiliki jarak tempat tinggal jauh dari puskesmas.
\end{abstract}

Kata Kunci $\quad$ : Pemanfaatan Puskesmas, Pengetahuan, Informasi, Keterjangkauan, Sikap

Published by:

Tadulako University

Article history :

Address:

Received :25 022021

Jl.Soekarno Hatta KM 9. Kota Palu, Sulawesi Tengah,

ed form : 25022021

Indonesia.

Accepted : 27022021

Phone: +628114120202

Email: Preventif.fkmuntad@gmail.com 


\begin{abstract}
The use of health services is a demand for consumers based on the need for pain, discomfort and the desire to prevent disease. Batanghari District Health Office data in 2019 shows that the Pasar Terusan Public Health Center has the lowest percentage of new patient visits, namely 19.2\%. The research design was cross sectional. The research was conducted in the working area of the Terusan Market Community Health Center in July 2020. The research sample was 95 people in the working area of the Pasar Terusan Community Health Center. The sampling technique was using purposive sampling technique. The instrument used was a questionnaire. Data were analyzed using the chi-square test. The results showed that $41.1 \%$ of respondents did not take advantage of puskesmas services, $32.6 \%$ had poor knowledge, $34.7 \%$ had incomplete information, $34.7 \%$ had difficult affordability and $35.8 \%$ stated that the officers' attitude was not good. The bivariate results show that there is a relationship between knowledge $(p=0.000)$, affordability $(p=0.030)$ and attitude of officers $(p=0.000)$ with the use of puskesmas services in the working area of the 2020 Pasar Terusan Community Health Center. There is no relationship between information and utilization. puskesmas services in the working area of the 2020 Pasar Terusan Community Health Center $(p=0.646)$. The Public Health Center needs to expand its network to reach people who live far from the Community Health Center.
\end{abstract}

Keywords: Utilization, Knowledge, Information, Affordability, Attitude of Officers

\title{
PENDAHULUAN
}

Puskesmas sebagai penanggung jawab penyelenggara upaya kesehatan terdepan, kehadirannya di tengah masyarakat tidak hanya berfungsi sebagai pelayanan kesehatan bagi masyarakat, tetapi juga sebagai pusat komunikasi masyarakat. Di samping itu, keberadaan Puskesmas di suatu wilayah dimanfaatkan sebagai upaya-upaya pembaharuan (inovasi) baik di bidang kesehatan masyarakat maupun upaya pembangunan lainnya bagi kehidupan masyarakat sekitar sesuai dengan kondisi sosial budaya masyarakat setempat. Oleh karena itu keberadaan Puskesmas dapat dapat diumpamakan sebagai agen perubahan di masyarakat sehingga masyarakat lebih berdaya dan timbul gerakan-gerakan upaya kesehatan masyarakat yang bersumber pada masyarakat (1).

Salah satu upaya pemerintah dalam rangka memeratakan pelayanan kesehatan kepada masyarakat adalah dengan penyediaan beberapa fasilitas pelayanan kesehatan terutama puskesmas dan puskesmas pembantu, penyediaan obat, penyediaan tenaga medis dan pencegahan penyakit menular, yang dapat menjangkau segala lapisan masyarakat hingga ke daerah terpencil (2). Berdasarkan profil kesehatan Indonesia tahun 2019, pemanfaatan atau utilisasi pelayanan kesehatan di puskesmas di Indonesia hanya 79.504 .594 (29,8\%) kunjungan (3). Sedangkan jumlah kunjungan pasien rawat jalan di Provinsi Jambi tahun 2019 sebesar 1.335.281 (37,4\%) kunjungan(4). 
Data Dinas Kesehatan Provinsi Jambi pada tahun 2019 jumlah puskesmas di Provinsi Jambi sebanyak 195 unit, yang terdiri dari 74 unit puskesmas rawat inap dan 121 unit puskesmas non rawat inap. Jumlah puskesmas di Provinsi Jambi setiap tahunnya mengalami peningkatan. Pada tahun 2017 sebanyak 183 unit, tahun 2018 sebanyak 186 unit dan tahun 2019 sebanyak 195 unit. Dari 195 unit, sebanyak 159 unit kondisi baik, 22 unit rusak ringan, 11 unit rusak sedang dan 3 unit rusak berat. Rasio puskesmas terhadap 30.000 penduduk di Provinsi jambi pada tahun 2017 sebesar 1,39 dan tahun 2018 sebesar 1,38. Dengan demikian rasio puskesmas mengalami penurunan(5).

Data Dinas Kesehatan Kabupaten Batang Hari tahun 2019 menunjukkan bahwa jumlah puskesmas yang ada di Kabupaten Batang Hari sebanyak 18 unit yang terdiri dari 8 unit puskesmas rawat inap dan 10 unit puskesmas non rawat inap. Kondisi puskesmas yang ada di Kabupaten Batang Hari diketahui 10 unit kondisinya baik, 5 unit kondisinya rusak ringan dan 3 unit kondisinya rusak sedang. Rasio puskesmas terhadap 30.000 penduduk di Kabupaten Batang Hari pada tahun 2018 sebesar 0,95. Dengan demikian rasio puskesmas per 30.000 penduduk di Kabupaten Batang Hari masih belum tercukupi atau mengalami kekurangan(6).

Pada tahun 2018 jumlah kunjungan pasien rawat jalan di Kabupaten Batanghari sebanyak 251.243 kunjungan yang terdiri dari 101.026 kunjungan baru dan 150.217 kunjungan lama. Jumlah kunjungan pasien baru di Kabupaten Batang Hari tahun 2018 sebanyak 101.026 kunjungan dan kunjungan pasien lama sebanyak 150.217 kunjungan. Dari 18 Puskesmas, puskesmas yang memiliki persentase kunjungan baru paling rendah adalah Puskesmas Pasar Terusan yaitu sebesar 19,2\%.

Saat melakukan survei awal di wilayah kerja Puskesmas Pasar Terusan diketahui bahwa masyarakat yang tidak memanfaatkan puskesmas, alasan tidak berkunjung ke puskesmas bervariasi, diantaranya karena lebih memilih jasa pelayanan kesehatan lainnya seperti lebih memilih ke dokter/bidan praktek, jarak yang sulit dijangkau, kurangnya pengetahuan tentang pelayanan puskesmas, kurangnya informasi tentang pelayanan kesehatan, faktor kesibukan mencari nafkah sehingga masyarakat lebih memilih pengobatan seadannya, sementara itu kegiatan-kegiatan puskesmas diluar gedung untuk memberikan pelayanan kesehatan langsung kepada masyarakat seperti pengadaan puskesmas keliling, kunjungan petugas kerumah penduduk belum dilaksanakan secara maksimal oleh petugas puskesmas tetapi puskesmas hanya mengutamakan pemberian pelayanan kesehatan di puskesmas saja sehingga masyarakat tidak bisa memanfaatkan puskesmas secara maksimal. 
Penelitian ini bertujuan untuk mengetahui faktor-faktor yang berhubungan dengan pemanfaatan puskesmas oleh masyarakat di wilayah kerja Puskesmas Pasar Terusan.

\section{METODE}

Penelitian ini dilakukan dengan metode kuantitatif dengan desain cross sectional untuk mengetahui faktor-faktor yang berhubungan dengan pemanfaatan pelayanan puskesmas oleh masyarakat di wilayah kerja Puskesmas Pasar Terusan Tahun 2020. Penelitian dilakukan di wilayah kerja Puskesmas Pasar Terusan pada Bulan Juli 2020. Sampel penelitian adalah masyarakat yang ada di wilayah kerja Puskesmas Pasar Terusan sebanyak 95 orang. Teknik pengambilan sampel menggunakan teknik purposive sampling. Instrumen yang digunakan adalah kuesioner. Teknik pengumpulan data dengan metode wawancara. Teknik analisis data untuk mengetahui hubungan antara variabel menggunakan uji chi-square dengan bantuan software SPSS.

\section{HASIL}

Hasil penelitian menunjukkan bahwa sebanyak $41,1 \%$ responden tidak memanfaatkan pelayanan puskesmas, 32,6\% memiliki pengetahuan kurang baik, 34,7\% mendapatkan informasi kurang lengkap, 34,7\% memiliki keterjangkauan sulit dan 35,8\% menyatakan sikap petugas kurang baik (tabel 1). Hasil bivariat menunjukkan ada hubungan antara pengetahuan $(\mathrm{p}=0,000)$, keterjangkauan $(\mathrm{p}=0,030)$, sikap petugas $(\mathrm{p}=0,000)$ dengan pemanfaatan pelayanan puskesmas di wilayah kerja Puskesmas Pasar Terusan Tahun 2020. Tidak ada hubungan antara informasi dengan pemanfaatan pelayanan puskesmas di wilayah kerja Puskesmas Pasar Terusan Tahun 2020 ( $\mathrm{p}=0,646)$ (Tabel 2)

Hasil penelitian menunjukkan bahwa sebanyak 41,1\% responden tidak memanfaatkan pelayanan puskesmas, 32,6\% memiliki pengetahuan kurang baik, 34,7\% mendapatkan informasi kurang lengkap, 34,7\% memiliki keterjangkauan sulit dan 35,8\% menyatakan sikap petugas kurang baik (tabel 1). Hasil bivariat menunjukkan ada hubungan antara pengetahuan $(\mathrm{p}=0,000)$, keterjangkauan $(\mathrm{p}=0,030)$, sikap petugas $(\mathrm{p}=0,000)$ dengan pemanfaatan pelayanan puskesmas di wilayah kerja Puskesmas Pasar Terusan Tahun 2020. Tidak ada hubungan antara informasi dengan pemanfaatan pelayanan puskesmas di wilayah kerja Puskesmas Pasar Terusan Tahun 2020 ( $\mathrm{p}=0,646)$ (Tabel 2) 
Tabel 1.

Gambaran Pengetahuan, Informasi, Keterjangkauan, Sikap Petugas dan Pemanfaatan Puskesmas di Wilayah Kerja Puskesmas Pasar Terusan

\begin{tabular}{llc}
\hline \multicolumn{1}{c}{ Variabel } & n & \% \\
\hline Pemanfaatan Puskesmas & & \\
\hline Tidak Memanfaatkan & 39 & 41,1 \\
Memanfaatkan & 56 & 58,9 \\
\hline Pengetahuan & & \\
\hline Kurang Baik & 31 & 32,6 \\
Baik & 64 & 67,4 \\
\hline Informasi & & \\
\hline Kurang Lengkap & 33 & 34,7 \\
Lengkap & 62 & 65,3 \\
\hline Keterjangkauan & \multicolumn{2}{c}{34,7} \\
\hline Sulit & 33 & 65,3 \\
Mudah & 62 & \\
\hline Sikap Petugas & \multicolumn{2}{c}{35,8} \\
\hline Kurang Baik & 34 & 64,2 \\
\hline
\end{tabular}

Sumber, Data Primer, 2020

Tabel 2.

Hubungan Pengetahuan, Informasi, Keterjangkauan, Sikap Petugas dengan Pemanfaatan Puskesmas di Wilayah Kerja Puskesmas Pasar Terusan

\begin{tabular}{|c|c|c|c|c|c|c|c|}
\hline \multirow{3}{*}{ Variabel } & \multicolumn{4}{|c|}{ Pemanfaatan Puskesmas } & \multirow{2}{*}{\multicolumn{2}{|c|}{ Total }} & \multirow{3}{*}{ p-value } \\
\hline & \multicolumn{2}{|c|}{ Tidak } & \multicolumn{2}{|c|}{ Memanfaatkan } & & & \\
\hline & n & $\%$ & $\mathbf{n}$ & $\%$ & $\mathbf{n}$ & $\%$ & \\
\hline \multicolumn{8}{|l|}{ Pengetahuan } \\
\hline Kurang Baik & 23 & 74,2 & 8 & 25,8 & 31 & 100 & \multirow{2}{*}{0,000} \\
\hline Baik & 16 & 25,0 & 48 & 75,0 & 64 & 100 & \\
\hline \multicolumn{8}{|l|}{ Informasi } \\
\hline Kurang Lengkap & 12 & 36,4 & 21 & 63,6 & 33 & 100 & \multirow[t]{2}{*}{0,646} \\
\hline Lengkap & 27 & 43,5 & 35 & 56,5 & 62 & 100 & \\
\hline \multicolumn{8}{|l|}{ Keterjangkauan } \\
\hline Sulit & 19 & 57,6 & 14 & 42,4 & 33 & 100 & \multirow[t]{2}{*}{0,030} \\
\hline Mudah & 20 & 32,3 & 42 & 67,7 & 62 & 100 & \\
\hline \multicolumn{8}{|l|}{ Sikap Petugas } \\
\hline Kurang Baik & 26 & 76,5 & 8 & 23,5 & 34 & 100 & \multirow[t]{2}{*}{0,000} \\
\hline Baik & 13 & 21,3 & 48 & 78,7 & 61 & 100 & \\
\hline
\end{tabular}

Sumber,: Data Primer, 2020

\section{PEMBAHASAN}

Hasil penelitian menunjukkan bahwa ada hubungan yang bermakna antara pengetahuan dengan pemanfaatan pelayanan kesehatan di Puskesmas Pasar Terusan Tahun 2020 $(\mathrm{p}=0,000)$. Hubugan yang bermakna dalam penelitian ini dimaksud semakin baik 
pengetahuan responden maka semakin tinggi untuk memanfaatkan pelayanan Puskesmas Pasar Terusan, begitupun sebaliknya semakin kurang baik pengetahuan responden maka semakin rendah pemanfaatan pelayanan puskesmas Pasar Terusan.

Pada hasil penelitian ini menunjukkan bahwa masyarakat yang memiliki pengetahuan cukup lebih cenderung untuk berkunjung ke puskesmas dibandingkan dengan yang memiliki pengetahuan kurang, oleh karena itu pengetahuan masyarakat memiliki pengaruh yang cukup besar pada masyarakat dalam memanfaatkan pelayanan puskesmas di Puskesmas Pasar Terusan.

Hasil penelitian ini sejalan dengan penelitian Fatimah \& Indrawati (2019) di Puskesmas Kagok Kota Semarang diperoleh hasil bahwa ada hubungan antara pengetahuan dengan pemanfaatan pelayanan Puskesmas Kagok Kota Semarang p=0,020)(7). Hasil penelitian Weku, et al (2018) di Puskesmas Kema diperoleh hasil bahwa ada hubungan pengetahuan dengan pemanfaatan pelayanan kesehatan di Puskesmas Kema $(\mathrm{p}=0,002)(8)$. Penelitian Zulfendri (2018) menunjukkan bahwa ada hubungan antara pengetahuan dengan pemanfaatan pelayanan IV A di wilayah kerja Puskesmas Padang Bulan(9). Hasil penelitian Ambar (2018) menunjukkan bahwa tidak ada hubungan antara pengetahuan dengan pemanfaatan pelayanan kesehatan pada peserta BPJS di Puskesmas Kombos Kecamatan Singkil Kota Manado(10).

Menurut asumsi peneliti, responden yang memiliki pengetahuan kurang baik dan tidak memanfaatkan pelayanan Puskesmas Pasar Terusan dikarenakan ketidaktahuan responden tentang puskesmas menyebabkan responden tidak ingin memanfaatkan pelayanan Puskesmas Pasar Terusan. Sedangkan responden yang memiliki pengetahuan baik dan memanfaatkan pelayanan Puskesmas Pasar Terusan tentunya sudah tahu pelayanan Puskesmas Pasar Terusan sehingga ingin memanfaatkan pelayanan puskesmas Pasar Terusan. Responden mengetahui tentang keberadaan Puskesmas Pasar Terusan, dikarenakan selama ini responden pernah memperoleh informasi tentang keberadaan dan fungsi Puskesmas dari Kader yang dipilih oleh Puskesmas serta dari pengelaman tetangga yang pernah memanfaatkan pelayanan puskesmas.

Berdasarkan hasil penelitian diperoleh nilai $p$-value $=0,646$ ( $p$-value $>0,05)$ sehingga menunjukkan bahwa tidak ada hubungan antara informasi dengan pemanfaatan pelayanan kesehatan di Puskesmas Pasar Terusan Tahun 2020. Kemudahan informasi yang dimaksud dalam penelitian ini merupakan kemudahan respoden dalam memperoleh informasi terkait 
pelayanan di Puskesmas dari berbagai sumber media baik media cetak, elektronik, maupun orang-orang terdekat.

Hasil penelitian ini tidak sejalan dengan penelitian yang dilakukan oleh Fatimah \& Indrawati (2019) di Puskesmas Kagok Kota Semarang diperoleh hasil bahwa ada hubungan antara kemudahan informasi dengan pemanfaatan pelayanan kesehatan di Puskesmas Kagok Kota Semarang $(\mathrm{p}=0,012)(7)$. Hasil penelitian ini juga tidak sejalan dengan penelitian Adriana, et al (2018) di Puskesmas Kawangu diperoleh hasil ada hubungan antara intensitas informasi dengan pemanfaatan fasilitas persalinan yang memadai di Puskesmas Kawangu $(\mathrm{p}=0,039)(11)$.

Menurut asumsi peneliti, tidak ada hubungan antara informasi dengan pemanfaatan pelayanan Puskesmas Pasar Terusan yang artinya baik responden yang mendapatkan informasi dan responden yang tidak mendapatkan informasi sama-sama memanfaatkan pelayanan Puskesmas Pasar Terusan. Responden yang kurang mendapatkan informasi dikarenakan selama ini promosi maupun publikasi terkait Puskesmas Pasar Terusan masih belum optimal. Hal tersebut terlihat bahwa puskesmas masih belum merata dalam mempromosikan pelayanan Puskesmas Pasar Terusan. Sedangkan responden yang mendapatkan informasi dikarenakan telah diberikan konseling oleh kader tentang pelayanan Puskesmas Pasar terusan.

Peneliti juga berasumsi bahwa, tidak ada hubungan antara informasi dengan pemanfaatan pelayanan Puskesmas Pasar Terusan dikarenakan sebagian besar responden menggunakan kartu BPJS sehingga jika responden sakit harus berobat ke Puskesmas Pasar Terusan. Selain itu ada beberapa responden yang tidak memanfaatkan pelayanan Puskesmas Pasar Terusan dikarenakan sulitnya akses yang ada membuat masyarakat kurang dalam memanfaatkan pelayanan puskesmas Pasar Terusan. Selain itu, kurangnya dukungan keluarga seperti mengantar keluarga jika ada anggota keluarga yang sakit juga mempengaruhi pemanfaatan pelayanan puskesmas.

Hasil penelitian menunjukkan bahwa ada hubungan yang bermakna antara keterjangkaun dengan pemanfaatan pelayanan kesehatan di Puskesmas Pasar Terusan Tahun $2020(\mathrm{p}=0,030)$. Semakin mudah akses ke Puskesmas maka responden semakin lebih memanfaatkan pelayanan puskesmas dan sebaliknya semakin sulit akses maka semakin rendah responden dalam memanfaatkan pelayanan puskesmas. 
Hasil penelitian menunjukkan bahwa ada hubungan antara keterjangkauan dengan pemanfaatan pelayanan kesehatan di Puskesmas Pasar Terusan. Responden yang memiliki keterjangkauan sulit lebih tidak memanfaatkan pelayanan puskemas. Hal tersebut dikarenakan jarak puskesmas yang jauh lebih dari 15 kilometer dan jalan yang rusak sehingga untuk menuju ke puskesmas membutuhkan waktu yang lama sehingga responden tidak memanfaatkan pelayanan Puskesmas. Selain itu ada wilayah kerja Puskesmas Pasar Terusan yaitu desa Malapari yang dekat dengan Muara Bulian sehingga masyarakat desa Malapari lebih memilih berobat ke Dokter/Bidan Praktek swasta yang ada di Muara Bulian.

Responden yang memiliki rumah dengan jarak tempuh yang jauh dari puskesmas Pasar Terusan tetap cenderung banyak memanfaatkan pelayanan kesehatan karena tidak ada pilihan pelayanan kesehatan yang lain, hal tersebut dikarenakan mereka menjadi peserta JKN yang berobat ditanggung oleh pemerintah. Menurut peneliti keterjangkauan dalam penelitian ini meliputi masalah jarak yang terlalu jauh dari rumah/permukiman masyarakat dan ketersediaan transportasi serta dana yang dibutuhkan untuk mencapai pelayanan kesehatan. Masyarakat yang memiliki kesulitan dalam hal ini tidak memiliki kendaraan serta transportasi umum yang sangat terbatas lebih memilih berobat ke praktek bidan dan membeli obat di warung saja.

Hasil penelitian ini sejalan dengan penelitian Siti Fatimah dan Fitri Indrawati (2019) yang menunjukkan bahwa ada hubungan antara aksesibilitas dengan pemanfaatan pelayanan kesehatan di Puskesmas $(\mathrm{p}=0,000)(7)$. Hasil penelitian ini sejalan dengan penelitian Bambang Irawan \& Asmaripa Ainy (2018) di wilayah kerja Puskesmas Payakabung diperoleh hasil bahwa ada hubungan antara aksesibilitas dengan pemanfaatan pelayanan kesehatan pada peserta jaminan kesehatan nasional di wilayah kerja Puskesmas Payakabung Kabupaten Ogan Ilir ( $\mathrm{p}=0,000)(12)$. Menurut Masita (2015) aksesibilitas merupakan akses yang harus dapat dicapai oleh masyarakat, tidak terhalang oleh keadaan geografis, sosial, ekonomi, organisasi dan bahasa(13)

Hasil penelitian menunjukkan bahwa ada hubungan yang bermakna antara sikap petugas dengan pemanfaatan pelayanan kesehatan di Puskesmas Pasar Terusan Tahun 2020 $(\mathrm{p}=0,000)$. Hubugan yang bermakna dalam penelitian ini dimaksud semakin baik sikap petugas saat memberikan pelayanan kepada pasien maka pasien akan memanfaatkan kembali pelayanan Puskesmas, begitupun sebaliknya semakin kurang baik sikap petugas maka pasien akan tidak memanfaatkan kembali pelayanan kesehatan. 
Hasil penelitian menunjukkan bahwa ada hubungan antara sikap petugas kesehatan dengan pemanfaatan pelayanan kesehatan ke Puskesmas di Puskesmas Pasar Terusan. Sikap petugas kesehatan yang kurang baik dalam memberikan pelayan kepada pasien maka akan mempengaruhi pasien dalam memanfaatkan kembali pelayanan di Puskesmas Pasar Terusan. Hal tersebut dikarenakan terkait dengan persepsi mutu pelayanan yang diterimanya. Jika responden memiliki persepsi yang baik terhadap mutu pelayanan maka pasien akan memiliki tingkat kepuasan yang baik sehingga akan mempengaruhi dalam pemanfaatan pelayanan ke puskesmas. Sikap petugas kesehatan dalam memberikaan pelayanan merupakan salah satu bentuk dari mutu pelayanan.

Dalam penelitian ini juga terdapat bahwa sikap petugas kesehatan kurang baik tetapi responden tetap memanfaatkan pelayanan kesehatan di Puskesmas Pasar Terusan dikarenakan responden tidak memiliki pilihan lain untuk memilih layanan kesehatan lainnya. Responden telah menjadi peserta JKN yang biaya berobatnya ditanggung oleh pemerintah atau gratis. Hal ini membuat persepsi mengenai sikap petugas kesehatan tidak mempengaruhi dalam pemanfaatan pelayanan kesehatan.

Hasil penelitian ini sejalan dengan penelitian yang dilakukan oleh Susi Sulastri ButarButar (2016) di Puskesmas Tandang Buhit Kecamatan Balige yang menyatakan bahwa ada hubungan antara sikap petugas dengan pemanfaatan pelayanan kesehatan oleh peserta BPJS golongan PBI di Puskesmas Tandang Buhit $(\mathrm{p}=0,033)(14)$. Hasil penelitian ini juga sejalan dengan penelitian Citra Wulandari, La Ode Ali Imran Ahmad \& Syawal K Sapta Putra (2016) di Puskesmas langara Kecamatan Wawonii diperoleh hasil bahwa ada hubungan antara sikap petugas dengan pemanfaatan pelayanan kesehatan di UPTD Puskesmas Langara Kecamatan wawonii Barat kabupaten Konawe Kepualauan ( $\mathrm{p}=0,0288)(15)$.

\section{KESIMPULAN DAN SARAN}

Faktor yang berhubungan dengan pemanfaatan pelayanan puskesmas di wilayah kerja Puskesmas Pasar Terusan adalah pengetahuan, keterjangkauan dan sikap petugas. Diharapkan kepada Dinas Kesehatan untuk membuat perencanaan terkait dengan pengadaan puskesmas keliling khususnya di wilayah kerja puskesmas Pasar Terusan sehingga dapat menjangkau masyarakat yang memiliki akses yang sulit. Petugas puskesmas perlu memberikan informasi kepada masyarakat tentang pelayanan kesehatan gratis di puskesmas 


\section{DAFTAR PUSTAKA}

1. Kemenkes RI. Profil Kesehatan Indonesia Tahun 2016. Jakarta: Kementerian Kesehatan Republik Indonesia; 2016.

2. Riskesdas. Riset Kesehatan Dasar Tahun 2018. Jakarta: Kementerian Kesehatan Republik Indonesia; 2018.

3. Kemenkes RI. Profil Kesehatan Indonesia Tahun 2018. Jakarta: Kementerian Kesehatan Republik Indonesia; 2019.

4. Dinkes Provinsi Jambi. Profil Kesehatan Provinsi Jambi Tahun 2019. Jambi: Dinas Kesehatan Provinsi Jambi; 2020.

5. Dinkes Provinsi Jambi. Profil Kesehatan Provinsi Jambi Tahun 2018. Jambi: Dinas Kesehatan Provinsi Jambi; 2019.

6. Dinkes Kabupaten Batanghari. Profil Kesehatan Kabupaten Batang Hari Tahun 2019. Jambi: Dinas Kesehatan Kabupaten Batang Hari; 2019.

7. Fatimah S, Indrawati F. Faktor Pemanfaatan Pelayanan Kesehatan di Puskesmas. Higeia J Public Heal Res Dev. 2019;3(1).

8. Weku. Analisis Faktor-faktor yang Berhubungan dengan Pemanfaatan Pelayanan Kesehatan di Puskesmas Kema Kecamatan Kema Kabupaten Minahasa Utara. J Kesehat Masy. 2018;1(2).

9. Zulfendri. Hubungan Pengetahuan, Sikap dan Karakteristik WUS dengan Pemanfaatan Pelayanan IVA di Wilayah Kerja Puskesmas Padang Bulan Kota Medan Tahun 2018. Universitas Sumatera Utara; 2018.

10. Ambar RZ. Hubungan Pengetahuan dengan Pemanfaatan Pelayanan Kesehatan pada Peserta BPJS di Puskesmas Kombos Kecamatan Singkil Kota Manado. Universitas Katolik De La Salle Manado; 2018.

11. Adriana. Akses Pelayanan Kesehatan Berhubungan dengan Pemanfaatan Persalinan Fasilitas yang Memadai di Puskesmas Kawangu. Public Heal Prev Med Arch. 2018;2(1).

12. Irawan B, Ainy A. Analisis Faktor-Faktor yang Berhubungan dengan Pemanfaatan Pelayanan Kesehatan pada Peserta JKN di Wilayah Kerja Puskesmas Payakabung, Kabupaten Ogan Ilir. J Ilmu Kesehat Masy. 2018;9(3).

13. Masita A, Yuniar N, Lisnawaty. Faktor-Faktor yang Berhubunngan dengan Pemanfaatan Pelayanan Kesehatan pada Masyarakat Desa Tanailandu di Wilayah Kerja Puskesmas Kanapa Napa Kecamatan Mawasangka Kabupaten Buton Tengah Tahun 2015. J Mhs Kesehat Masy. 2015;1(3).

14. Butar-Butar SS. Faktor-Faktor yang Berhubungan dengan Pemanfaatan Pelayanan kesehatan Oleh Peserta BPJS Golongan PBI di Puskesmas Tandang Buhit Kecamatan Balige Tahun 2016. Universitas Sumatera Utara; 2016.

15. Wulandari. Faktor yang Berhubungan dengan Pemanfaatan Pelayanan Kesehatan di UPTD Puskesmas Langara Kecamatan Wawonii Barat Kabupaten Konawe Kepualauan Tahun 2016. J Kesehat Masy. 2016;2(2). 